\title{
Penerapan Model Pembelajaran Inkuiri Terbimbing Untuk Meningkatkan Kemampuan Berpikir Kreatif Siswa di SMAN 2 Kota Bengkulu
}

\author{
Wage Klaudhi Sintya, Andik Purwanto, Indra Sakti \\ Prodi Pendidikan Fisika FKIP-UNIB \\ E-mail: viviwg74@gmail.com
}

\begin{abstract}
ABSTRAK
Penelitian ini bertujuan untuk mengukur peningkatan kemampuan berpikir kreatif dan aktivitas belajar siswa X MIPA E SMAN 2 Kota Bengkulu. Penelitian ini merupakan penelitian tindakan kelas. Subjek dalam penelitian ini adalah seluruh siswa kelas X MIPA E yang berjumlah 30 orang. Aktivitas siswa dinilai melalui pengamatan lembar observasi aktivitas dengan rentang nilai antara 1 sampai 3. Kemampuan berpikir kreatif diukur menggunakan lembar tes yang berbentuk soal uraian di setiap akhir siklus. Hasil penelitian ini menunjukkan bahwa aktivitas belajar siswa pada siklus I dengan rata-rata skor sebesar 22,5 pada kategori cukup, siklus II sebesar 25 pada kategori cukup dan siklus III sebesar 27 pada kategori baik. Kemampuan berpikir kreatif siswa pada siklus I diperoleh ketuntasan belajar klasikal sebesar 50\% (tuntas), meningkat pada siklus II diperoleh ketuntasan belajar sebesar 93,33\% (tuntas), dan meningkat pada siklus III diperoleh ketuntasan belajar sebesar 100\% (tuntas). Nilai rata-rata kemampuan berpikir kreatif siswa pada siklus I diperoleh sebesar 72,17, pada siklus II sebesar 82,33, siklus III sebesar 88,83 pada predikat kreatif sampai sangat kreatif. Berdasarkan hasil penelitian dapat disimpulkan bahwa penerapan model pembelajaran inkuiri terbimbing dapat meningkatkan kemampuan berpikir kreatif dan aktivitas belajar siswa di kelas X MIPA E SMAN 2 Kota Bengkulu.
\end{abstract}

Kata kunci: Model Pembelajaran Inkuiri Terbimbing, Kemampuan berpikir kreatif, Aktivitas belajar siswa.

\begin{abstract}
ABSTRAK
This study aims to measure the improvement of creative thinking skills and student learning activities $\mathrm{X}$ MIPA E SMAN 2 Kota Bengkulu. This research is a classroom action research. The subjects in this study were all students of class X MIPA E totaling 30 people. Student activity is assessed through observation of activity observation sheets with a range of values between 1 and 3. Creative thinking skills are measured using a test sheet in the form of a description item at each end of the cycle. The results of this study indicate that student learning activities on the first cycle with an average score of 22.5 on the category enough, cycle II of 25 on the category enough and the third cycle of 27 in either category. Students' creative thinking ability in cycle I was obtained by completion of classical learning by $50 \%$ (complete), increased in cycle II obtained learning completeness of $93.33 \%$ (complete), and increased in cycle III obtained 100\% complete learning completeness (thorough). The average score of students' creative thinking ability in the first cycle was obtained at 72.17 , in the second cycle of 82.33 , the third cycle was 88.83 on creative predicate until very creative. Based on the results of the study can be concluded that the implementation of guided inquiry learning model can improve the ability of creative thinking and student learning activities in class X MIPA E SMAN 2 Kota Bengkulu.
\end{abstract}

Keywords: Guided Inquiry Learning Model, Creative thinking ability, Student learning activity.

\section{PENDAHULUAN}

Dalam pembelajaran fisika, kemampuan berfikir kreatif merupakan hal yang sangat penting untuk dimiliki oleh siswa. Hal ini menunjukkan bahwa pelajaran fisika bukan hanya untuk menghapal fakta, prinsip, dan konsep yang ada, tetapi juga bagaimana menerapkan dan mengembangkan sesuatu yang baru dari teori yang diperoleh. Ciri-ciri orang yang memiliki kemampuan berpikir kreatif yang tinggi yaitu: 1) Memiliki dorongan ingin tahu yang besar. 2) Sering mengajukan pertanyaan yang baik 3) sering mengemukakan banyak gagasan dan usul terh 
adap suatu masalah 4) Bebas dalam menyatakan pendapat 5) Menonjol dalam salah satu bidang seni 6) Memiliki pendapat sendiri dan mampu mengutarakannya 7) Tidak mudah terpengaruh orang lain 8) Daya imajinasi kuat 9) Memiliki tingkat orisionalitas yang tinggi 10) Dapat bekerja sendiri 11) Senang mencoba hal-hal yang baru ${ }^{[1]}$.

Berdasarkan observasi dan analisis kondisi pembelajaran di SMA Negeri 2 Kota Bengkulu, siswa belum dapat mengembangkan kemampuan berfikir kreatif pada saat pembelajaran berlangsung. Hal ini dapat dilihat dari banyaknya siswa yang belum bisa mengungkapkan gagasangagasannya dengan lancar, dan belum bisa mengembangkan atau memperkaya gagasan orang lain. Adapun permasalahan yang lain yaitu : 1) Masih banyaknya siswa yang tidak sepenuhnya memperhatikan materi yang disampaikan dan hanya sedikit saja siswa yang aktif bertanya dan menjawab pertanyaan saat proses belajar mengajar berlangsung 2) siswa belum bisa memberikan bermacam-macam penafsiran terhadap suatu masalah, gambar, atau cerita yang diberikan oleh guru 3) Siswa juga masih belum bisa menemukan alternatif lain untuk memecahkan suatu masalah yang ada.

Model pembelajaran inkuiri terbimbing merupakan salah satu model pembelajaran yang dapat mengembangkan keterampilan berpikir kreatif siswa. Model pembelajaran inkuiri terbimbing juga sesuai dengan kurikulum 2013 yang kini diterapkan dalam satuan pendidikan dengan menggunakan pendekatan saintifik dalam penerapannya. perangkat pembelajaran IPA berbasis inkuiri terbimbing dapat melatih kemampuan berpikir kreatif dan pemahaman konsep ${ }^{[2]}$ Melalui inkuiri terbimbing siswa dapat mengalami sendiri proses pencarian fakta-fakta yang kemudian diuji, dievaluasi, dan dipergunakan untuk memecahkan masalah, dengan memberikan pertanyaan dan permasalahan siswa dapat menemukan kemungkinan-kemungkinan jawaban dari permasalah, yang tidak lain adalah keterampilan berpikir kreatif $^{[3]}$ dengan langkah-langkah model pembelajaran inkuiri terbimbing adalah sebagai berikut: 1) Prapembelajaran 2) Menetapkan Masalah 3) Merumuskan hipotesis 4) Melaksanakan Penelitian/ Eksperimen 5) Mengolah dan Menganalisis Data 6) Menguji hipotesis 7) Menarik kesimpulan 8) Menyajikan Hasil 9) Pascapembelajaran ${ }^{[4]}$.

Berdasarkan permasalahan yang ada, maka dipandang perlu dilakukan perbaikan proses pembelajaran yaitu dengan menerapkan model pembelajaran yang dapat meningkatkan kemampuan berpikir kreatif siswa. Salah satu alternatifnya adalah penerapan model pembelajaran inkuiri terbimbing untuk meningkatkan kemampuan berpikir kreatif siswa di kelas X MIPA E SMAN 2 Kota Bengkulu. Dengan permasalahan apakah model pembelajaran inkuiri terbimbing dapat meningkatkan aktivitas dan keampuan berpikir kreatif siswa kelas X MIPA E SMAN 2 Kota Bengkulu. Sehingga penelitian ini bertujuan untuk mengetahui peningkatan aktivitas belajar siswa dan kemampuan berpikir kreatif siswa kelas X MIPA E SMAN 2 Kota Bengkulu. kemampuan berpikir kreatif Dengan penerapan model pembelajaran inkuiri terbimbing mampu meningkatkan kemampuan berpikir kreatif siswa dengan jumlah peningkatan sebesar $40,3 \%{ }^{[5]}$.

\section{METODE PENELITIAN}

Penelitian ini merupakan penelitian tindakan kelas (Classroom Action Research). Subjek dalam penelitian ini adalah seluruh siswa kelas X MIPA E di SMAN 2 Kota Bengkulu tahun ajaran 2017/2018 yang berjumlah 30 siswa. Pelaksanaan penelitian tindakan kelas dilakukan sebanyak tiga siklus. Instrumen penelitian yang digunakan dalam penelitian ini berupa lembar observasi aktivitas guru dan siswa, dan lembar tes.

Lembar observasi digunakan untuk mengetahui aktivitas respon siswa terhadap proses pembelajaran dan untuk mengetahui kekurangan-kekurangan yang dilakukan guru pada saat mengajar. Dengan kisaran nilai dalam kategori seperti pada Tabel 1.

Tabel 1. Interval kategori penilaian observasi aktivitas guru dan siswa

\begin{tabular}{ccc}
\hline No & Interval & Kategori \\
\hline 1 & $9-14$ & Kurang \\
\hline 2 & $15-20$ & Cukup \\
\hline 3 & $21-27$ & Baik \\
\hline
\end{tabular}


Lembar tes digunakan untuk mengukur kemampuan berpikir kreatif siswa. Bentuk tes yang digunakan dalam penelitian ini berupa tes uraian untuk mengukur kemampuan berpikir kreatif siswa pada materi usaha dan energi yang diberikan kepada siswa setiap akhir siklus setelah proses pembelajaran selesai. lembar tes dalam penelitian ini berjumlah empat butir soal yang terdiri dari soal kemampuan berpikir lancar, kemampuan berpikir luwes, kemampuan berpikir asli, dan kemampuan berpikir memperinci. Dengan kisaran nilai seperti pada Tabel 2. ${ }^{[6]}$

Tabel 2. Penilaian kemampuan berpikir kreatif

\begin{tabular}{lccc}
\hline No. & $\begin{array}{c}\text { Nilai kemampuan } \\
\text { berpikir kreatif }\end{array}$ & Tingkat & $\begin{array}{c}\text { Tingkatan kemampuan } \\
\text { berpikir kreatif }\end{array}$ \\
\hline 1 & $81-100$ & 4 & Sangat Kreatif \\
\hline 2 & $61-80$ & 3 & Kreatif \\
\hline 3 & $41-60$ & 2 & Cukup Kreatif \\
\hline 4 & $21-40$ & 1 & Kurang kreatif \\
\hline 5 & $0-20$ & 0 & Tidak Kreatif \\
\hline
\end{tabular}

\section{HASIL DAN PEMBAHASAN}

3.1 Hasil

\subsubsection{Hasil observasi aktivitas siswa}

Hasil observasi aktivitas siswa dari siklus ke siklus dapat dilihat pada Gambar 1.

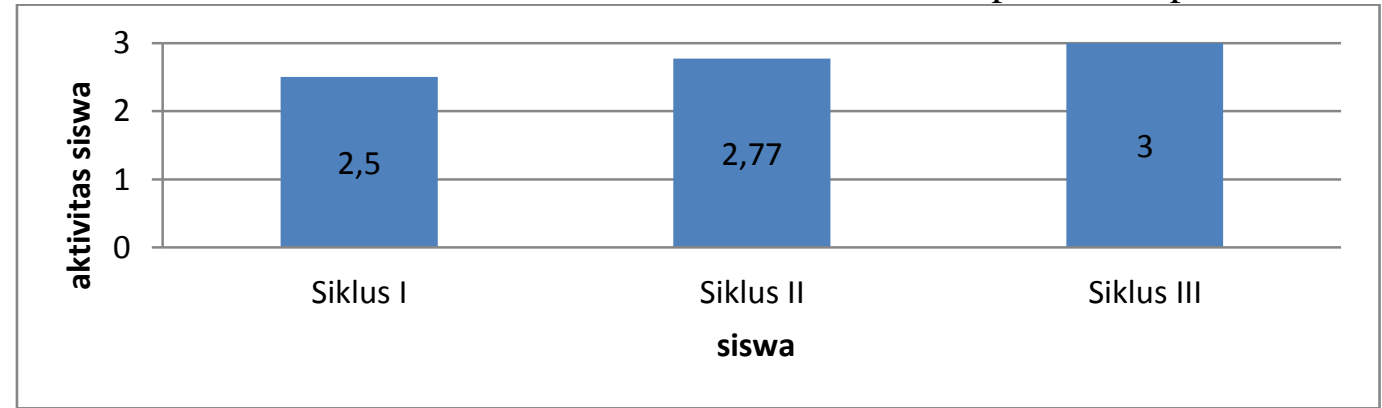

3.1.2 Hasil kemampuan berpikir kreatif siswa

\section{Gambar 1. Grafik rata-rata aktivitas siswa}

Data hasil kemampuan berpikir kreatif siswa dari siklus ke siklus dapat di lihat pada Gambar 2.

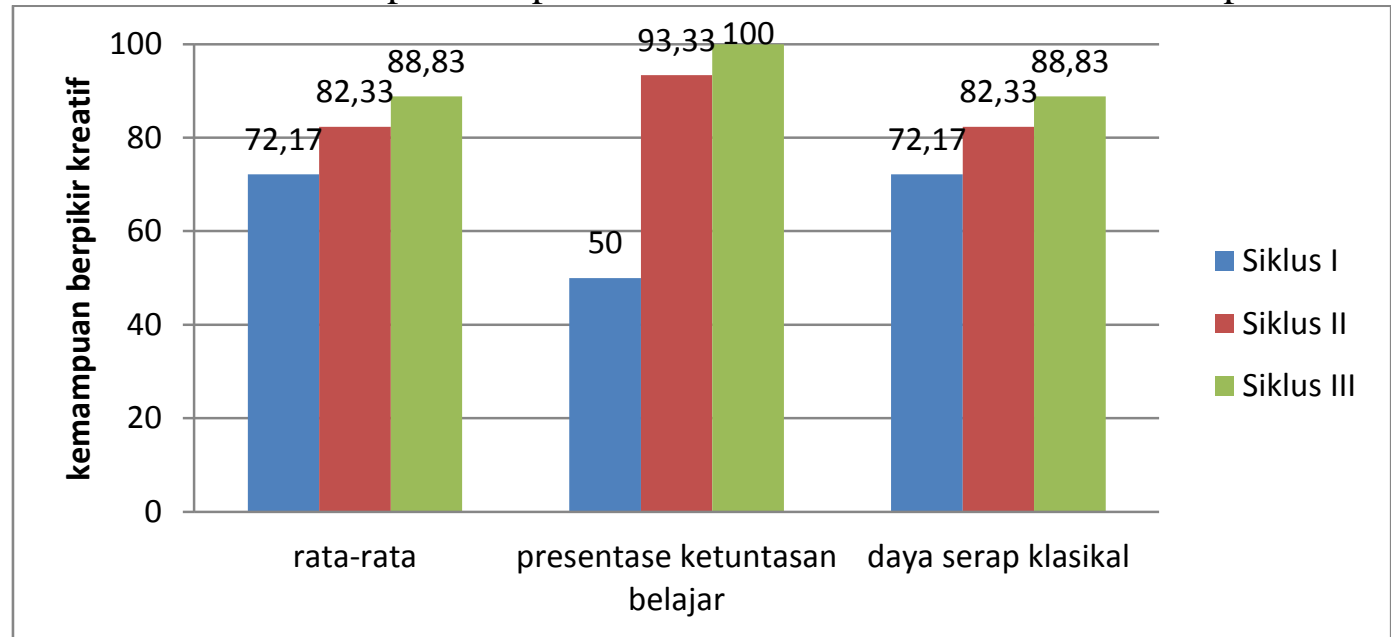

\subsection{Pembahasan}

\section{Gambar 2. Grafik skor kemampuan berpikir kreatif siswa}

\subsubsection{Deskripsi aktivitas belajar siswa}

Aktivitas siswa merupakan seluruh kegiatan yang dilakukan siwa selama proses pembelajaran berlangsung. Aktivitas siswa dinilai melalui pengamatan menggunakan lembar observasi aktivitas siswa yang telah disesuaikan dengan langkah-langkah model pembelajaran Inkuiri terbimbing. Berdasarkan hasil penelitian dengan menerapkan model pembelajaran inkuiri terbimbing, dari tiga 
siklus yang telah di laksanakan terjadi peningkatan aktivitas belajar siswa. pada siklus I rata-rata skor aktivitas siswa yaitu 2,5, kemudian meningkat pada siklus II yaitu 2,77, dan kembali meningkat pada siklus III yaitu 3. Sehingga dapat disimpulkan bahwa aktivitas belajar siswa telah mencapai indikator keberhasilan penelitian dimana siklus III lebih baik dari siklus II dan siklus II lebih baik dari siklus I yang berarti model pembelajaran inkuiri terbimbing dapat meningkatkan aktivitas belajar siswa di kelas X MIPA E SMAN 2 Kota Bengkulu.

Ada proses pembelajaran dengan penerapan model pembelajaran Inkuiri terbimbing secara keseluruhan langkah-langkah pembelajaran telah dilakukan dengan baik, namun pada siklus I dan II masih terdapat langkah yang belum maksimal untuk dilakukan yaitu pra pembelajaran, menetapkan masalah, melaksanakan penelitian, mengolah dan menganalisis data, dan menguji hipotesis. Pada langkah pra pembelajaran pada siklus I dan II masih banyak siswa yang tidak fokus pada stimulus yang diberikan, siswa masih fokus pada kegiatan masing-masing di luar pembelajaran. Pada langkah menetapkan masalah pada siklus I dan II siswa masih ragu-ragu dalam merumuskan permasalahan sehingga waktu yang dibutuhkan cukup lama. Pada saat melaksanakan penelitian pada siklus I dan II masih terdapat siswa yang tidak aktif dan tidak bekerja sama dalam kelompoknya. Pada kegiatan mengolah data pada siklus I dan II siswa masih belum bisa mengolah data dengan benar, sehingga siswa masih cenderung menunggu guru untuk menjelaskan satu persatu. Pada langkah menguji hipotesis pada siklus I dan II beberapa siswa masih ragu dan belum berani mengungkapkan pendapatnya tentang keberterimaan hipotesis yang di buatnya. Aktivitas siswa pada siklus I sampai dengan III berada pada kategori baik. Tidak ada aktivitas siswa yang berada pada kategori kurang. Secara keseluruhan proses pembelajaran yang dilakukan oleh siswa telah berjalan dengan baik pada siklus I, siklus II, dan siklus III yang ditandai dengan peningkatan skor rata-rata aktivitas siswa pada tiap siklusnya.

\subsubsection{Deskripsi kemampuan berpikir kreatif siswa}

Kemampuan berpikir kreatif diukur menggunakan lembar Tes disetiap akhir siklus. Tes ini terdiri dari 4 soal berbentuk soal uraian yang sesuai dengan indikator kemampuan berpikir kreatif. Sebelum diterapkan soal tes ini terlebih dahulu divalidasi oleh 1 orang dosen FKIP Fisika Universitas Bengkulu dan 2 orang guru Fisika SMA Negeri 2 Kota Bengkulu. Hasil penelitian menunjukkan bahwa kemampuan berpikir kreatif siswa meningkat pada setiap siklus. Pada siklus I terdapat sebanyak 24 siswa berada pada kelompok yang memiliki interprestasi penilaian pada kategori kreatif dan 3 orang siswa berada pada kelompok yang memiliki kemampuan berpikir kreatif dengan interprestasi penilaian sangat kreatif. 3 orang siswa yang memiliki kemampuan berpikir kreatif pada interprestasi cukup kreatif, dan 1 orang siswa yang memiliki kemampuan berpikir kreatif pada interprestasi penilaian kurang kreatif. hasil perhitungan dari 30 siswa diperoleh rata-rata nilai kemampuan berpikir kreatif adalah 72,17 dengan standar deviasi sebesar 10,14. Terdapat sebanyak 15 siswa yang mendapat nilai diatas rata-rata, dan terdapat 15 siswa yang mendapat nilai dibawah rat-rata. Pada siklus II terdapat 17 siswa berada pada kelompok yang memiliki interprestasi penilaian pada kategori kreatif dan 12 orang siswa berada pada kelompok yang memiliki kemampuan berpikir kreatif dengan interprestasi penilaian sangat kreatif. Dari hasil tes kemampuan berpikir kreatif yang telah dilakukan terdapat 1 orang siswa yang memiliki kemampuan berpikir kreatif pada interprestasi cukup kreatif. Hasil perhitungan dari 30 siswa diperoleh rata-rata nilai kemampuan berpikir kreatif adalah 82,33 dengan standar deviasi sebesai 8,34. Terdapat sebanyak 12 siswa yang mendapat nilai diatas rata-rata, dan terdapat 18 siswa yang mendapat nilai dibawah rat-rata. Pada siklus III terdapat sebanyak 7 orang siswa berada pada kelompok yang memiliki interprestasi penilaian pada kategori kreatif dan 23 orang siswa berada pada kelompok yang memiliki kemampuan berpikir kreatif dengan interprestasi penilaian sangat kreatif.

Hasil perhitungan dari 30 siswa pada siklus III diperoleh rata-rata nilai kemampuan berpikir kreatif adalah 88,83 dengan standar deviasi adalah 6,41. Terdapat sebanyak 21 siswa yang mendapat nilai diatas rata-rata, dan terdapat 9 siswa yang mendapat nilai dibawah rat-rata. Hasil penelitian menunjukkan penerapan model pembelajaran Inkuiri terbimbing dapat meningkatkan 
kemampuan berpikir kreatif siswa. hal ini dibuktikan dengan rata-rata nilai kemampuan berpikir kreatif siswa pada siklus I, siklus II, dan siklus III telah mencapai indikator keberhasilan dimana lebih dari $75 \%$ dari jumlah seluruh siswa yang memperoleh interprestasi penilaian dengan kategori kreatif hingga sangat kreatif. Rata-rata kemampuan berpikir kreatif siswa juga meningkat pada setiap siklusnya Selain itu, daya serap juga klasikal meningkat tiap siklus.

\section{SIMPULAN DAN SARAN}

\subsection{SIMPULAN}

Penerapan model pembelajaran inkuiri terbimbing dapat meningkatkan aktivitas belajar siswa pada konsep Usaha dan Energi di kelas X MIPA E SMAN 2 Kota Bengkulu. Hal ini dapat dilihat dari meningkatnya rata-rata aktivitas belajar siswa yang awalnya berapa pada interprestasi penilaian dalam kategori cukup dan meningkat pada kategori baik.

Penerapan model pembelajaran inkuiri terbimbing dapat meningkatkan kemampuan berpikir kreatif siswa pada konsep Usaha dan Energi di kelas X MIPA E SMA Negeri 2 kota Bengkulu. Hal ini dapat dilihat dari meningkatnya rata-rata nilai kemampuan berpikir kreatif siswa, pada siklus I diperoleh persentase ketuntasan belajar sebesar 50\%, daya serap klasikal 72,17\% dengan nilai ratarata 72,17 yang artinya kemampuan berpikir kreatif siswa berada pada kategori kreatif ; pada siklus II diperoleh persentase ketuntaan belajar sebesar 93,33\%, daya serap klasikal 82,33\% dengan nilai rata-rata 82,33 yang artinya kemampuan berpikir kreatif siswa dalam kategori sangat kreatif; siklus III diperoleh persentase ketuntasan belajar sebesar 100\%, daya serap klasikal 88,83\% dengan nilai rata-rata 88,83 yang artinya kemampuan berpikir kreatif siswa berada pada kategori sangat kreatif.

\subsection{SARAN}

Sebaiknya dalam menggunakan model pembelajaran inkuiri terbimbing untuk meningkatkan kemampuan berpikir kreatif siswa guru harus benar-benar bisa menguasai kelas dengan baik dan bisa membimbing siswa secara merata saat pembelajaran berlangsung agar siswa bisa memperhatikan pelajaran dan siswa bisa memahami pelajaran secara maksimal.

\section{DAFTAR PUSTAKA}

[1] Munandar, U. (2009). Pengembangan kreativitas Anak Berbakat. Jakarta: Rineka Cipta.

[2] Mufiannoor, E., Hidayat, M. T., \& Soetjipto. (2016). Melatih Kemampuan Berfikir Kreatif dan pemahaman Konsep dengan Pembelajaran berbasis inkuiri terbimbing pada Materi Interaksi Makhlik Hidup dengan Lingkungan. Pendidikan Sains pascasarjana Universitas Negeri Surabaya.

[3] Yanti, N. S., Yusrizal, \& Gani, A. (2016). Penerapan Model Pembelajaran Inkuiri Terbimbing untuk Meningkatkan Keterampilan Berpikir Kreatif dan Motivasi Siswa Ditinjau dari Jenis Kelamin pada Materi Kalor Kelas X SMAN 11 Banda Aceh. Jurnal Pendidikan Sains Indoneesia.

[4] Abidin, Y. (2016). Desain Sistem Pembelajaran Dalam Konteks Kurikulum 2013. Bandung: Refika Aditama.

[5] Putra, R. D., Rinanto, Y., Dwiastuti, S., \& Irfa'i, I. (2015). Peningkatan Kemampuan Berpikir Kreatif Siswa melalui Model Pembelajaran Inkuiri terbimbing pada Siswa kelas XI MIA 1 SMA Negeri Colomadu Karanganyar Tahun Pelajaran 2015/2016. Proceeding Biologi Education Conference.

[6] Marlina, I., Fransisca, C., \& Hamdani, D. (2015). Upaya Meningkatkan Kemampuan Berpikir Kreatif dan Aktivitas Belajar Siswa pada Konsep Indera Penglihatan dan Alat Optik 
Melalui Model Problem Based Intruction (PBI) Berbabis pendekatan Saintifik di Kelas VIII 4 SMPN 1 Kota Bengkulu. Bengkulu: Universitas Bengkulu. 